\title{
Controle da Corrupção e Burocracia da Linha de Frente: Regras, Discricionariedade e Reformas no Brasil*
}

\author{
Fernando Filgueiras ${ }^{1}$ \\ Ana Luiza Melo Aranha \\ ${ }^{1}$ Professor do Departamento de Ciência Política da Universidade Federal de Minas Gerais \\ (UFMG); coordenador do Centro de Referência do Interesse Público (CRIP/UFMG). Belo \\ Horizonte, MG, Brasil. (e-mail: fernandofilgueiras@hotmail.com) \\ ${ }^{2}$ Doutoranda em Ciência Política do Programa de Pós-Graduação em Ciência Política da \\ Universidade Federal de Minas Gerais (UFMG); pesquisadora do Centro de Referência do \\ Interesse Público (CRIP/UFMG). Belo Horizonte, MG, Brasil (e-mail: \\ aninharanha@gmail.com)
}

\section{INTRODUÇÃO}

$\mathrm{O}$

Brasil tem experimentado, desde os anos de 1990, um conjunto de mudanças institucionais na gestão pública. Foram aprimorados procedimentos e regras institucionais para o exercício das atividades de gerência, os papéis e o alcance dos burocratas nos processos decisórios das políticas públicas e os mecanismos de controle da gestão, tendo em vista indicadores de resultados, responsabilização fiscal e práticas de transparência. Ou seja, o Brasil tem experimentado um processo de mudança positiva nos padrões de gestão pública, o que representa inovações importantes para a consecução de políticas públicas mais eficazes e efetivas, no contexto de um projeto de democratização do Estado.

No entanto, ao mesmo tempo em que experimenta mudanças importantes na gestão, o Brasil sofre da permanência da corrupção em uma espécie de agenda negativa da esfera pública. O Brasil vive, desde a democratização, uma sucessão de escândalos políticos que minam a legitimidade do Estado e criam um sentimento de impunidade que paira na sociedade brasileira. O resultado desse processo é uma visão co-

\footnotetext{
* Agradecemos ao Escritório das Nações Unidas sobre Drogas e Crime (UNODC) e à Controladoria Geral da União (CGU), bem como à Fundação Konrad Adenauer (FKA), o apoio logístico e financeiro que possibilitaram as pesquisas que este artigo relata.
}

DADOS - Revista de Ciências Sociais, Rio de Janeiro, vol. 54, n-2, 2011, pp. 349 a 387. 
mum do Estado como o espaço dos vícios, e da corrupção como prática corriqueira e recorrente na administração pública. Essa sucessão de escândalos políticos e a presença forte de um sentimento de impunidade fazem com que a corrupção reforce uma cultura pública atávica, em que a corrupção é um comportamento natural e necessário dos indivíduos quando estes conseguem auferir as benesses do Estado.

O Brasil vive, portanto, um paradoxo. O aprimoramento da gestão não foi seguido de uma diminuição da percepção da corrupção. $\mathrm{O}$ artigo parte deste problema: o que explica o fato de as inovações gerenciais da administração pública brasileira, especialmente com a implantação dos mecanismos da nova gestão pública, não terem resultado em uma diminuição da percepção da corrupção por parte da cidadania? Diante deste problema, propomos a seguinte hipótese: apesar das inovações gerenciais da administração pública, não houve mudança na percepção da corrupção pelo fato de as reformas gerenciais não terem afetado os burocratas da linha de frente, ou seja, os burocratas que se relacionam diretamente com o cidadão e que usam sua discricionariedade indevidamente para auferir ganhos com propina e suborno. Isto ocorre pelo fato de as mudanças institucionais da administração pública não terem afetado a cultura pública dos servidores da linha de frente, não permitindo constituir um universalismo dos procedimentos no conjunto dos órgãos que compõem a máquina administrativa do Estado brasileiro.

Com base em duas pesquisas de survey, uma com cidadãos e outra com servidores públicos a respeito da corrupção no Brasil, testamos esta hipótese, observando o contexto de mudanças institucionais e o papel dos burocratas ao nível da rua (street-level bureaucracy) na consecução da accountability na gestão pública. O artigo estará dividido em três seções. Na primeira, tratamos do contexto de transformações na administração pública durante os anos de 1980 e 1990, configurando dois tipos ideais que seriam a administração burocrática e a nova gestão pública. Estes tipos ideais são constituídos a partir do problema do controle e da discricionariedade. Na segunda seção, descrevemos a experiência brasileira com as mudanças institucionais na gestão pública e, finalmente, testamos a hipótese referida acima, com base no tratamento quantitativo dos dados resultantes da pesquisa com os servidores públicos. 


\section{BUROCRACIA, DISCRICIONARIEDADE E ACCOUNTABILITY}

Desde meados dos anos de 1980, os países do centro do capitalismo e os países em desenvolvimento têm experimentado um conjunto de reformas administrativas com o objetivo de aprimorar os instrumentos de governança e fortalecer a eficiência do Estado no contexto de sociedades e mercado globais. De um modo geral, estas reformas priorizaram o tema da eficiência da máquina administrativa, propondo um conjunto de mudanças organizacionais que absorvessem instrumentos de gestão próprios do setor privado.

O paradigma da nova gestão pública (new public management) emergiu contra o modelo burocrático de matriz weberiana. O declínio do modelo burocrático ocorreu, sobretudo, pela crise do Welfare State, a qual compreendeu elementos políticos e econômicos associados a mudanças estruturais das sociedades capitalistas (Offe, 1985). No que tange aos elementos econômicos da crise do Welfare State, a crise fiscal e as pressões referentes às dívidas públicas colocaram em xeque a capacidade do Estado de assegurar o financiamento da estrutura administrativa necessária para a concretização dos direitos, especialmente dos direitos sociais. Por outro lado, o Welfare State se viu contraído pelo consenso que emergiu nos países do centro do capitalismo de que a saída para a crise seria a diminuição do tamanho do Estado e a diminuição do papel do Estado no mercado.

Nesse contexto mais amplo de transformações do Estado ao longo dos anos de 1980 e 1990, houve um conjunto de transformações das máquinas administrativas, com o claro objetivo de rever o paradigma burocrático, com o condão de assegurar-lhe maior eficiência. O modelo burocrático do Welfare State concentrar-se-ia naquilo que Weber (2002) denominou como processo de dominação racional-legal, tendo em vista um conjunto de características definidoras de um padrão de relação entre o Estado e a sociedade, marcado pela racionalidade do capitalismo e de suas instituições. Em primeiro lugar, a burocracia caracteriza-se pela existência de jurisdições fixas e oficiais, ordenadas por meio de regulamentos e diretivas postas em um ordenamento jurídico positivo. A legitimidade desse tipo de organização do Estado deriva exclusivamente da lei, que é interpretada racionalmente por um corpo de magistrados. As atividades dos burocratas, portanto, são válidas à luz de regulamentos e códigos legais, em que estas atividades são distribuídas como deveres oficiais e em que a autoridade para ordenar surge 
de uma hierarquia fixa e estável, cabendo aos chefes tomarem as medidas necessárias para a realização metódica desses deveres. O princípio da hierarquia nas burocracias significa um sistema ordenado de mando e subordinação, no qual superiores supervisionam e controlam os inferiores. Outra característica definidora da burocracia, segundo Weber, é o fato de a organização basear suas atividades em documentos escritos, e pelo fato de as atividades serem realizadas por especialistas (ibidem).

Central para o conceito de burocracia é o fato de que todas as atividades realizadas pelos burocratas são controladas no contexto da hierarquia funcional e legitimadas a partir do texto legal. As burocracias surgem, de acordo com Weber, no contexto de sociedades que passam pelo processo de modernização e convivem com o politeísmo dos valores, em que a autoridade sagrada e tradicional perde o seu sentido em sociedades que vivem o mundo dos interesses e a diversidade dos fins. Nesse sentido, a burocracia, de acordo com Weber, é um mecanismo fundamental de "socialização das relações de poder", sendo um instrumento de poder de primeira ordem (ibidem). Ademais, é fundamental observar o caráter permanente, universal e impessoal da burocracia. Permanente porquanto, nas sociedades modernas, a burocracia é o instrumento de socialização do poder. A burocracia é universal, uma vez que se baseia na premissa de uma concepção funcional e racional de regulamentos e códigos que reconheçam a igualdade formal daqueles que estão sujeitos a ela. E, por fim, uma vez que reconheça a igualdade formal dos cidadãos como princípio constituinte, a burocracia é uma forma impessoal do poder, legitimada pela legalidade e não pela vontade do soberano (ibidem).

A partir do conceito weberiano de burocracia, configurou-se uma relação direta entre as formas organizacionais e administrativas, tanto privadas quanto públicas, e a política, propriamente dita. Na chave weberiana do conceito de burocracia, ela é uma forma de socialização do poder, sendo, por conseguinte, um instrumento de poder de primeira ordem. Ou seja, quem controla a burocracia tem poder. E o elementar dessa relação entre as organizações burocráticas e a política é o fato da discricionariedade. Uma vez que se baseia na existência de uma legalidade posta pelo Estado e fundamentada racionalmente, bem como parte do princípio da impessoalidade e da hierarquia, os burocratas não devem ter margem de discricionariedade em sua ação cotidiana em um tipo ideal de burocracia. A discricionariedade pode ser defini- 
da, de acordo com Davis (1969), como a margem de liberdade de um funcionário público para escolher um curso de ação ou inação, fundamentada na lei. A discricionariedade está envolvida pelos códigos legais e não se trata de ação ilegal, mas de liberdade para agir ou deixar de agir que um funcionário público tem diante do cidadão comum (Galligan, 1990).

Como está baseado na impessoalidade e na universalidade dos procedimentos, o modelo burocrático de administração pública estabelece que o controle se concentra, sobretudo, nos meios de administração, tendo em vista a legalidade instituída pelo Estado. O processo decisório sobre as políticas públicas teria notória influência dos burocratas, devendo basear-se na sua compatibilidade com os preceitos legais, de acordo com o controle dos meios. Contudo, a decisão final cabe à política, restando à burocracia implementar as políticas apontadas e decididas pela autoridade política. Ou seja, em um modelo ideal de burocracia, não cabe ao burocrata discricionariedade para decidir o conteúdo das políticas públicas. O princípio da hierarquia e a fixação de jurisdições buscam reduzir a margem de discricionariedade dos agentes públicos, fazendo com que o interesse público fique indisponível. No âmbito das organizações burocráticas, o tema do controle torna-se, portanto, fundamental para a construção da legitimidade. Isto é, as patologias institucionais da burocracia ocorrem quando a universalidade dos procedimentos, a impessoalidade e o princípio da hierarquia são corrompidos. O controle, no contexto das organizações burocráticas do Welfare State, deve ser exercido para assegurar que a discricionariedade dos agentes públicos não resulte em corrupção.

Ao contrário disso, a ampliação da margem de discricionariedade dos agentes públicos e a falta de controles, com base na não universalidade dos procedimentos, fazem surgir a corrupção como mazela organizacional. É importante observar que o conceito de corrupção tem uma fluidez semântica e se aplica distintamente a diferentes contextos e gramáticas na dimensão da política. De uma forma geral, a corrupção significa o juízo que a sociedade formula a respeito da integridade de indivíduos e instituições com base em valores expressos em normas com as quais todos possam concordar (Filgueiras, 2008). Neste sentido, diferentes tipos de ação podem configurar um quadro de corrupção, tais como o clientelismo, o nepotismo, a patronagem e outras. Estes tipos de ação têm uma natureza peculiar, mas podem representar a corrupção na medida em que configurem um tipo de ação ilegítima a partir do 
interesse público. Desta forma, a corrupção deve ser compreendida nos parâmetros do discurso político, assumindo um caráter plástico e flexível que se aplica a diferentes contextos. No caso das burocracias do Estado liberal, o parâmetro normativo para definir a corrupção é o da legalidade como elemento central da legitimidade (ibidem). Para os fins deste artigo, partimos da premissa de que a corrupção é a elevação de interesses privados sobre o interesse público, tendo em vista o recorte do fenômeno na dimensão da organização burocrática do Estado. No caso da corrupção na dimensão da burocracia, tomamos como pressuposto que ela ocorre quando um burocrata usa indevidamente sua margem de discricionariedade para favorecer seus interesses privados em detrimento do interesse público (Gardiner, 2005; Philp, 2005).

No contexto da experiência do Welfare State, especialmente nos países de tradição anglo-saxã, o controle da corrupção deve ser exercido fortalecendo a burocracia e reduzindo a margem de discricionariedade dos burocratas. Em uma fórmula bastante simples, maior a margem de discricionariedade dos burocratas, maior a corrupção. No caso dos países de tradição anglo-saxã, a emergência do modelo burocrático de Welfare State, no contexto dos anos de 1940 e 1950, é uma resposta ao modelo de social work, pelo qual a discricionariedade dos burocratas implicaria desigualdade na aplicação dos recursos públicos e políticas públicas não universalistas (Diller, 2000). No caso do controle, a corrupção seria mitigada pelo reforço da máquina burocrática, especialmente no que diz respeito aos controles dos meios. A universalidade dos procedimentos e a impessoalidade das relações de poder fazem com que o controle da corrupção ocorra observando exclusivamente a legalidade e a sequência de procedimentos-padrão e rotineiros da atividade burocrática. Neste sentido, no modelo burocrático o controle seria exercido com a criação de mais burocracia, conforme um legalismo originário e legitimador da ação dos burocratas.

A crise do Welfare State e os movimentos por reformas, por outro lado, implicaram a construção de novos modelos de gestão. Neste sentido, a burocracia e a atuação das instituições de controle implicariam ineficiência e ampliação das práticas de corrupção. No contexto do desenvolvimento econômico, a corrupção poderia ser, inclusive, funcional para a redução de barreiras burocráticas que impediriam a acumulação de capital e gerariam, por conseguinte, custos de transação (Leff, 1964). A criação de mais burocracia para perseguir a integridade dos 
funcionários públicos implicaria mais custos para o setor público e mais corrupção, à medida que a burocratização se ampliasse e se tornasse corriqueira (Anechiarico e Jacobs, 1996). E, por fim, a ampliação da burocracia teria como resultante a possibilidade de constituição do comportamento rent-seeking por parte de políticos e burocratas, além das externalidades negativas advindas do número de órgãos, documentos e processos necessários para a realização dos fins (Krueger, 1974). Neste sentido, não basta reduzir a margem de discricionariedade do agente público, é fundamental submetê-lo a controle público sem que disso resulte mais burocratização.

A resposta a esse tipo de questionamento, que relaciona o aumento da burocracia com a ampliação da corrupção, foi a proposição de um conjunto de reformas administrativas que tomassem o parâmetro da eficiência como fundamental à constituição da burocracia. Esta abordagem chama a atenção para a necessidade de reformas institucionais, visando à consolidação do mercado e da democracia. Estas reformas partem do horizonte de que os interesses devem estar relacionados a regras fixas para a interação do público com o privado. As reformas institucionais devem caminhar no sentido de restringir os sistemas de incentivo à corrupção, minimizando o papel das burocracias estatais no desenvolvimento (Bardhan, 2006). As reformas consolidadas ao longo dos anos de 1980 e 1990 partiram da necessidade de diminuir o papel das burocracias, porquanto minimizariam os monopólios existentes, restringindo a cobrança de subornos e a presença da propina. Do ponto de vista das reformas institucionais para o combate à corrupção, a mudança deve ser realizada entre os sistemas de incentivo e a eficiência burocrática (Anechiarico e Jacobs, 1996). Ou seja, as reformas institucionais não devem reforçar o poder da burocracia, uma vez que elas resultariam em mais discricionariedade e incentivo para o pagamento de propina e de suborno, ou seja, em ampliação das práticas de corrupção. No aspecto formal, que representa um consenso entre analistas ligados a teorias neoinstitucionalistas, a prática de corrupção não é coibida mediante reforço do poder burocrático, mas pelo fomento do mercado (Rose-Ackerman, 1999).

O modelo da nova gestão pública, desta forma, assume que ela deve se basear na profissionalização da gestão; na preferência por indicadores quantitativos e padrões explícitos de mensuração de performance; no controle quantitativo de resultados; na distribuição de recursos de acordo com a performance da política; na descentralização das ativida- 
des da burocracia; na competição entre agências do Estado; na flexibilidade da gerência; na disciplina no dispêndio de recursos; no corte de custos diretos; e na criação de limites aos custos de transação da burocracia pública (Pollitt, 2003). O paradigma da nova gestão pública, portanto, ao assumir que a administração pública deve se basear na administração do setor privado, entende que a política deve ser pensada a partir da economia, de acordo com a teoria das falhas de mercado, que tem na eficiência o problema central das políticas públicas (Bozeman, 2007). O elemento central da nova gestão pública é reforçar a capacidade decisória dos gestores públicos aumentando a capacidade discricionária dos burocratas de alto nível (ground-level bureaucracy).

Neste sentido, a nova gestão pública convive com um conflito inerente à sua constituição, que passa, por um lado, pelo reforço da liderança e capacidade de gestão dos burocratas, o que demanda a ampliação de seu poder discricionário; e, por outro lado, pela redução dos controles burocráticos em favor do controle por metas, isto é, o controle dos fins, e não o controle dos meios. O controle, portanto, deve ser realizado a partir dos resultados obtidos em confrontação com os padrões pactuados e esperados de desempenho dos gestores. O controle, para a nova gestão pública, não deve se basear no controle dos meios e dos processos empregados para realizar as atividades da burocracia, mas na performance dos gestores para alcançar os resultados esperados. Portanto, o controle não deve se basear em auditorias e processos, mas em resultados objetivos que ampliem os recursos disponíveis ao público por meio da diminuição dos custos.

A nova gestão pública reforçou o papel dos gestores, ampliando seu poder discricionário. E frente a essa ampliação do poder discricionário dos gestores, defende-se o princípio da accountability como meio para diminuir os custos da delegação, dentre eles os custos da corrupção. A accountability é compreendida como o princípio a partir do qual se responsabiliza o agente público perante o cidadão. O debate a respeito do conceito de accountability surgiu ao longo dos anos de 1980 e 1990, no contexto das reformas para enfrentar a crise do Welfare State. A perspectiva da nova gestão pública, no que tange à questão dos custos da delegação, foi fortemente influenciada pela teoria da agência, que defende uma perspectiva econômica da política baseada em uma teoria microeconômica da firma (Dowdle, 2006). A accountability seria compreendida na relação entre o principal - aquele que delega, ou seja, os cidadãos - e os agents - aqueles que são delegados, ou seja, os agentes 
públicos. Reforçar a accountability e ampliar a margem de controle significaria ampliar a compatibilidade de incentivos entre principal e agent e ampliar a base de informação disponível ao cidadão para julgar a ação dos agentes públicos. No que tange a este último aspecto, o reforço da accountability ocorreria com a ampliação da transparência (Heald, 2006).

Da perspectiva da nova gestão pública, accountability e transparência são usados como termos intercambiáveis, o que causa sérias confusões no que diz respeito ao problema da responsabilização (Lindstedt e Naurin, 2010; Etzioni, 2010). Dentre os problemas elencados acima, destacamos o fato de a perspectiva da nova gestão pública considerar o processo da accountability em uma concepção mais sistêmica e pouco afeita ao processo de implementação das políticas públicas. Ou seja, a nova gestão pública estabeleceu um paradoxo no que tange à relação entre gestão e controle. De um lado, ela procura reforçar a discricionariedade dos gestores com poderes de decisão. Mas, por outro lado, procura reforçar o controle e reduzir a margem de discricionariedade daqueles funcionários públicos que estão no plano da implementação, ou seja, os funcionários públicos que estão no nível da rua (street-level bureaucracy). A contradição entre gestão e controle burocrático ocorre na medida em que a ampliação da discricionariedade dos gestores não é seguida da desburocratização do controle.

De acordo com Michael Lipsky (2010), os burocratas ao nível da rua compreendem os implementadores como parte relevante do processo de tomada de decisão sobre políticas públicas. De acordo com Lipsky, estes burocratas (street-level bureaucrats) compreendem aqueles indivíduos que se relacionam diretamente com os cidadãos e enfrentam os dilemas de implementação de políticas. Esta perspectiva de street-level bureaucracy considera algumas premissas fundamentais, dentre elas: 1) os burocratas do nível da rua necessariamente têm discricionariedade e são forçados a usá-la; 2) desenvolvem formas próprias de gerir seu trabalho; 3) têm uma forte vinculação com sua formação profissional; 4) em sua interação com os cidadãos, têm discricionariedade para decidir sobre a vida de outras pessoas (Lipsky, 2010). A nova gestão pública ampliou a margem de discricionariedade dos altos gestores, mas reforçou os mecanismos de controle sobre o burocrata do nível da rua, tendo em vista o desenvolvimento de técnicas de auditoria e aferição de resultados. 
A literatura internacional sobre o tema do controle, no contexto das discussões sobre a nova gestão pública, tem priorizado uma concepção de accountability balizada em uma relação vertical entre cidadãos e representantes ou em uma relação horizontal entre agências do Estado (O'Donnell, 1999). Estas perspectivas da direção da accountability são fortemente normativas, desconsiderando o papel que os burocratas da linha de frente, ou seja, o papel que os burocratas do nível da rua têm na consecução da responsabilização perante os cidadãos (Hupe e Hill, 2007). São esses burocratas que se relacionam diretamente com os cidadãos e criam, por suas ações, a percepção que aqueles têm sobre o serviço público e sobre o alcance da corrupção no interior do Estado. Pensar a atuação dos burocratas do nível da rua é fundamental para pensar o tema da accountability, partindo da premissa de que a governança democrática é multidimensional e tem diferentes camadas (Hupe e Hill, 2007).

Se tomarmos o pressuposto de que os burocratas do nível da rua têm importância para a consolidação da accountability, é fundamental perquirir o que eles pensam do controle burocrático e qual o seu papel na questão do controle da corrupção. Uma vez que eles se relacionam diretamente com os cidadãos, é fundamental questionar de que forma sua ação impacta na percepção do cidadão comum sobre a corrupção e de que forma sua percepção sobre as instituições de controle tem consequências para o enfrentamento da corrupção. O objetivo deste artigo é relacionar estas duas ordens de problemas a partir do caso brasileiro.

\section{A BUROCRACIA E O DESENVOLVIMENTO DAS INSTITUIÇÕES DE CONTROLE NO BRASIL}

As asserções apresentadas na seção anterior estão inseridas no contexto de debate do mundo anglo-saxão. O caso brasileiro difere-se da experiência anglo-saxônica pelo fato de a criação da burocracia no Brasil ocorrer no interior de um sistema patrimonialista. A teoria do patrimonialismo é uma vertente interpretativa do Brasil, que tomou forma por meio de um projeto de modernização do Estado, da economia e da sociedade que passa pela ideia de ruptura com nosso passado ibérico e pela afirmação de um modelo de organização estatal moderna, pautado pela impessoalidade e pela racionalidade na relação entre Estado e sociedade (Werneck Vianna, 1999). A teoria do patrimonialismo brasileiro, como desenvolvida por Raymundo Faoro, significa a apropriação de conceitos da sociologia weberiana para interpretar a realidade 
brasileira à luz da nossa tradição ibérica. De acordo com Faoro (2000), o patrimonialismo no Brasil seria um sistema de dominação realizado por um estamento que se aloja na burocracia do Estado com o objetivo de ver reconhecido os seus interesses privados como o interesse público. De acordo com Faoro, o patrimonialismo seria uma viagem redonda em que os estamentos tradicionais da sociedade portuguesa renovariam sua dominação alojando-se na máquina do Estado.

A proposta normativa da teoria do patrimonialismo é promover uma ruptura com o passado ibérico e proporcionar um projeto de modernização calcado na racionalidade do capitalismo e de suas instituições. A ruptura com o passado, para Faoro, significa a afirmação de um modelo weberiano de Estado, fundamentado em uma concepção modernizante capaz de fazer submergir nossos vícios de origem, balizados no patrimonialismo, que não significa uma teoria da corrupção, mas, no caso brasileiro, é uma corrente que permite a interpretação da corrupção em suas diferentes dimensões. A ruptura com o patrimonialismo ocorreria pela modernização, em particular, do Estado e de sua estrutura administrativa.

Ao longo do século $X X$ a sociedade brasileira assumiu um largo debate sobre a gestão pública e a modernização do Estado. O objetivo era a busca dos elementos de racionalização e transformação cultural capazes de balizar um projeto de formação da ordem pública conforme os ditames do capitalismo e do desenvolvimento político. Dessa maneira, a partir dos anos de 1930, tendo em vista esse projeto modernizador conduzido pelo Estado, os temas da administração e da gestão pública tornaram-se centrais. A partir desse momento, produziu-se, no Brasil, uma série de reformas no aparato administrativo do Estado, tendo como finalidade a implosão de nosso passado patrimonialista, a afirmação de uma racionalidade típica do Ocidente e o fim da corrupção como prática cotidiana e corriqueira (Carvalho, 2008). A corrupção, como um suposto traço de caráter do brasileiro, seria combatida se a ruptura com o passado patrimonialista e estamental da administração pública se concretizasse mediante a modernização da máquina administrativa. Nesse contexto, as reformas administrativas no Brasil ocuparam, e ainda ocupam, um lugar central no projeto de modernização, respeitando um processo planejado de transformação.

Com a criação do Departamento Administrativo do Serviço Público (DASP) em 1938, o Estado brasileiro dava os primeiros passos para o 
projeto de modernização. A criação do DASP fundamentou-se na reforma do sistema de pessoal, na implantação e simplificação de sistemas administrativos e das atividades de orçamento público, de acordo com um modelo burocrático. $\mathrm{O}$ objetivo era aprimorar a eficiência do serviço público (Marcelino, 2003). No que diz respeito à reforma do sistema de pessoal, a criação do DASP alinhavou-se à construção de um Estado corporativo, em que a noção de serviço público obedeceria à criação de um corpo técnico de excelência subordinado ao chefe do Executivo. A administração pública assumiria, dessa maneira, as características de um sistema autônomo, centrado em uma visão procedimental e legalista de serviço público, de acordo com o modelo weberiano. No interior de um projeto de modernização pelo alto, conduzido pelo Estado Novo, a reforma da administração pública brasileira, no plano federal, centrou-se no Executivo e em sua capacidade técnica, dando a esse Poder a condução das reformas de acordo com um projeto centralizador e autoritário. A primeira reforma da gestão pública no Brasil surgiu, portanto, do autoritarismo centralizador e do fortalecimento do Executivo e de suas capacidades técnicas, ou seja, da sua racionalidade formal (Cardoso, 1982).

O primeiro impulso reformista entrou em colapso a partir de 1945, com a queda do Estado Novo. A implantação do modelo weberiano de administração pública nos anos de 1930 e 1940 encontrou sua primeira barreira formada pela crescente desorganização, pelo personalismo e pela corrupção. A desorganização crescente do DASP com a reconstrução da democracia, em 1946, resultou na nomeação de extranumerários no serviço civil, na desorganização dos orçamentos públicos, da compra de materiais e dos mecanismos de controle da burocracia, e, por fim, na expansão da ineficiência do modelo de gestão implantado. Isso se deveu, como nota Marcelino, à característica central da reforma administrativa implementada no Estado Novo, que focou na reforma dos meios de administração sem pensar a reforma dos fins, ou seja, as atividades substantivas da administração pública (Marcelino, 2003).

A corrupção, nesse contexto de crescente desorganização do DASP, fez com que o controle corporativista do serviço público desse lugar à existência de uma máquina sindical que seria, de acordo com os liberais, um "antro de favorecimentos ilícitos" (Motta, 2008, p. 244). No dizer de Faoro, o erro da Era Vargas foi manter o sistema centralizado de controle da economia pelo Estado, reforçando a "viagem redonda" que sempre caracterizou a história social do Brasil (Faoro, 2000). A corrup- 
ção avançou no período dos anos de 1950 e 1960, uma vez que passou a ocupar a esfera pública de modo permanente, contribuindo para uma crise de legitimação que assolou a Segunda República. As crescentes denúncias contra os chefes dos Executivos, o favorecimento de empreiteiras e a ocupação desenfreada das estatais levou a um quadro de agravamento da corrupção na cena pública brasileira, sendo ela um dos elementos centrais para a justificação retórica de reconstrução do autoritarismo no Brasil (Starling, 2008). Havendo essa expansão retórica da corrupção e o "perigo" iminente do comunismo, a manutenção do projeto de modernização do Estado e da sociedade passaria pela recomposição da autoridade central e pelo enfrentamento do patrimonialismo que foi escamoteado ao longo do período do Estado Novo. Dada a posição do pensamento autoritário de que o Brasil não estaria apto para a democracia, a modernização apenas se concretizaria com a elevação do Estado sobre a sociedade e a condução, pelo alto, das reformas (Filgueiras e Borges Filho, 2005).

O modelo weberiano de administração pública foi substituído em 1967, com o Decreto-Lei 200, já no regime militar, inaugurando uma nova onda de modernização do aparelho de Estado. No contexto do desenvolvimentismo, a expansão da intervenção do Estado na economia e a criação da administração indireta representaram os elementos fundamentais para a continuidade do projeto de modernização e eliminação do passado patrimonialista. O resultado foi a multiplicação de entidades da administração indireta, mediante a criação de fundações, empresas públicas, sociedades de economia mista e autarquias (Marcelino, 2003).

O modelo de administração indireta respeitava a noção de que a ampliação da eficiência do serviço público e o controle das delinquências do homem público brasileiro passariam pela adoção de modelos de administração pública mais próximos aos modelos da administração privada. Os órgãos da administração indireta, em sua maioria, são pessoas jurídicas de direito privado - fundações, sociedades civis ou concessionárias do setor público - que têm um padrão de gestão mais flexível, já que são regidas pela legislação comercial e civil e não pelo direito administrativo. O objetivo, com o modelo de administração indireta, era descentralizar a administração pública brasileira, levando-a a todos os cantos do país, com o lema da desburocratização em vista. 
A descentralização administrativa está relacionada à descentralização dos quadros da administração federal, da administração pública para a órbita privada e da União para os governos locais. Argumenta-se que a descentralização nascente do Decreto-Lei 200 promoveu mais eficácia da administração pública brasileira, ao permitir que ela se adaptasse às mudanças advindas com o desenvolvimento, uma vez que o decreto não seria uma norma determinística, mas a constituição de um plano indicativo, no qual estavam presentes conceitos e princípios administrativos, que delimitavam mais as atividades-fim do serviço público (ibidem).

Com o fim do autoritarismo e com a transição para a democracia a partir de 1985, o modelo de administração pública do Decreto-Lei no 200 esfacelou-se com sua crescente desorganização e desarticulação. O objetivo de plena descentralização da administração pública federal não se cumpriu e o objetivo das reformas para o desenvolvimento não se concretizaram na cena pública brasileira. O autoritarismo, ao contrário do que afirma Marcelino, potencializou os problemas históricos da administração pública brasileira, resultando no descontrole financeiro, na falta de responsabilização de governantes e burocratas perante a sociedade, na politização indevida da burocracia, além da fragmentação excessiva das empresas públicas, com a perda de foco na atuação governamental (Abrucio, 2007). Nesse quadro de desorganização da administração pública brasileira, a corrupção emergiu como prática recorrente na democracia, criando a sensação, tão presente no senso comum, de que ela nasceu com a democratização, e não como herança do regime autoritário.

Diante desses problemas, ao longo da Nova República planejou-se um conjunto de reformas que mantivessem o compromisso assumido ao longo de nossa história republicana com a modernização. Para combater o legado do regime autoritário, as principais mudanças vieram com a Constituição de 1988, que contém um capítulo específico a respeito da organização político-administrativa do Estado. No âmbito das atividades constituintes, destaca-se a ideia de democratização do Estado, com o fortalecimento do controle externo da administração pública, especialmente o papel do Ministério Público e da sociedade civil. É na Constituição de 1988 que os princípios regentes da administração pública brasileira são encontrados, especialmente no que diz respeito à legalidade, à publicidade e à moralidade administrativa (CRFB, art. 37). Além disso, é importante salientar o papel da descentralização es- 
tipulado pela Constituição, bem como o compromisso estabelecido de reforma do serviço civil por meio do reconhecimento e da universalização da meritocracia e da participação da cidadania (ibidem).

Uma primeira linha interpretativa das reformas busca atualizar o tema do patrimonialismo. Apesar do reconhecimento atribuído pela Constituição à importância das reformas na administração pública, a corrupção permaneceu como uma prática corriqueira e cotidiana na cena pública, havendo uma sucessão de escândalos que atestam a ineficiência dos meios administrativos e a permanência das mazelas do patrimonialismo. Apesar de todas as reformas, o personalismo permaneceu como prática na Nova República, sendo ele uma forma de aglutinação de grupos preferenciais no aparato estatal, porque não tinha havido, até então, uma ruptura com o passado patrimonialista. Ou seja, apesar das reformas administrativas realizadas ao longo dos últimos 70 anos, a gestão pública brasileira ainda é, segundo essa vertente de interpretação do Brasil, bastante patrimonialista, fazendo com que práticas como a corrupção, o clientelismo, o nepotismo e a patronagem ainda permaneçam.

A nosso ver, essa chave interpretativa do Brasil demonizou o Estado, o que proporcionou, ao longo dos anos 90, uma série de reformas do Estado centradas mais na busca de seu enfraquecimento e no fortalecimento do mercado (Campante, 2003). A Nova República inaugurou mudanças na administração pública, com a finalidade de aprimorar a máquina governamental e criar mecanismos de governança capazes de responder à nova realidade internacional. Estabeleceu-se que essas reformas deveriam estar balizadas na redução do formalismo, na democratização do serviço público, na dinamização das atividadesmeio, no controle do Poder Executivo pelo Poder Legislativo e na transparência dos mecanismos de controle.

Durante o governo Collor, promoveu-se uma reforma administrativa motivada pela "caça aos marajás", a qual procurava recompor os mecanismos da gestão pública, organizá-la e combater a corrupção que assolava o serviço público brasileiro. De imediato, houve a reincorporação à administração direta das funções de governo que eram exercidas pela administração indireta. Evitou-se a proliferação de empresas estatais e de fundações sem fontes próprias de recursos, além de promover maior controle sobre elas. O ponto principal das reformas administrativas do período Collor foi o desmonte da máquina estatal, com a 
ideia de "enxugar" o quadro de pessoal. O impeachment e o fracasso de suas reformas mostraram que o problema da governabilidade seria o ponto central para a ideia de uma reforma mais ampla do Estado brasileiro (Skidmore, 1999).

Um quadro mais agravado de corrupção demandava reformas mais profundas na administração pública brasileira. No curto período do governo Itamar Franco, a única realização nesse sentido foi a criação de um Código de Ética Profissional do Servidor Público Civil da Administração Federal, conforme Decreto 1.171, de 22 de junho de 1994. No que concerne às reformas da administração pública, é no governo Fernando Henrique Cardoso que elas encontraram substrato político, com a implantação do Ministério da Administração e Reforma do Estado (MARE), criado em 1995, sob comando do ministro Bresser-Pereira. O diagnóstico de esfacelamento do serviço civil exigiria uma estratégia de reforma que possibilitasse a elevação da performance e a transformação do sistema de delegação e controle entre as agências do setor público (Bresser-Pereira, 2007).

A reforma administrativa conduzida pelo MARE procurou redefinir os setores de atuação estatal, reforçando a ideia de democratização do Estado e de mecanismos de gestão configurados em torno da adoção de modelos de administração privada para o setor público. No que diz respeito à identificação dos setores de atuação estatal, o MARE partiu da construção de quatro ramos de atuação que são: (a) o Núcleo Estratégico, que corresponde aos poderes da República e ao Ministério Público, em que as diretrizes, leis e políticas são formuladas e avaliadas; (b) o Setor de Atividades Exclusivas do Estado, no qual são realizadas as políticas públicas e atividades que apenas o Estado pode efetuar; é nesse setor que se inserem as agências executivas; (c) o Setor de Serviços Não-Exclusivos do Estado, que corresponde às autarquias e fundações públicas e às empresas públicas e de economia mista que operam com serviços públicos, mas que não são exercidos apenas pelo Estado; (d) o Setor de Produção de Bens e Serviços para o Mercado, que corresponde às atividades voltadas para o lucro, especialmente realizadas pelas empresas estatais. É nesse setor que ocorreriam as privatizações no serviço público brasileiro (MARE, 1995).

No que diz respeito ao modelo de administração adotado e à diferenciação dos setores de atuação do Estado na sociedade e na economia, a reforma administrativa do governo Fernando Henrique Cardoso assu- 
miu o modelo da nova gestão pública, cujo objetivo era adequar a administração pública brasileira às novas necessidades advindas da globalização dos mercados, da presença cada vez maior da legislação internacional de comércio e do aperfeiçoamento dos mecanismos de gestão. As mudanças foram implementadas de acordo com o modelo da nova gestão pública, que definiu que as atividades do governo devem se basear numa gestão pública similar à gestão realizada no mundo privado, porquanto seja o cidadão um cliente de serviços realizados pelo Estado (Bresser-Pereira, 2001). Ademais, procurou-se, com estas reformas, reforçar o papel dos gestores na formulação das políticas públicas, dando-lhes poderes decisórios.

De acordo com Abrucio (2007), apesar dos percalços pelos quais a reforma administrativa do governo passou, houve avanços nos mecanismos de gestão e uma mudança cultural no interior do serviço público brasileiro, de maneira que podemos perceber mudanças substanciais ocorridas nos dois mandatos de Fernando Henrique Cardoso. As reformas, no entanto, não ocorreram incólumes a eventuais barreiras a seu sucesso. As barreiras às reformas estão relacionadas, de acordo com Abrucio, a uma visão economicista estreita, que barrou várias inovações institucionais, como mais autonomia às agências reguladoras. As barreiras a estas inovações foram motivadas pelo medo de o Estado perder o controle sobre o dispêndio financeiro das agências. Para Rezende (2009), a prioridade do ajuste fiscal não permitiu o avanço da agenda de reformas na gestão, especialmente no que diz respeito ao aprimoramento dos incentivos às boas práticas no setor público.

Abrucio aponta, ainda, como ganhos da inovação gerencial implementada pela reforma administrativa do governo Fernando Henrique Cardoso: a gestão fiscal do Estado, que trouxe o incremento de de economicidade no setor público; as inovações no plano dos governos subnacionais, que introduziram o paradigma gerencialista nas políticas públicas; a criação de mecanismos mais apurados de avaliação das políticas públicas, especialmente na área social, o que permite melhor gerenciamento da aplicação de recursos; a adoção de planejamento no setor público, não no sentido tecnocrático, mas pela integração de programas de governo e projetos; a adoção do governo eletrônico, que mais avançou no âmbito dos estados, com a introdução de pregão eletrônico e organização das informações (Abrucio, 2007). Como aponta Abrucio, falta ainda o reforço de quatro eixos centrais nas reformas da administração pública brasileira, nos quais o governo Fernando Henrique Car- 
doso e o governo Lula pouco avançaram, que são: (a) na profissionalização da burocracia brasileira, especialmente nos cargos considerados estratégicos; (b) na eficiência dos serviços prestados; (c) na efetividade das políticas públicas; (d) na accountability e no reforço da transparência nas relações entre Estado e sociedade (ibidem).

Apesar dos avanços na criação de informação e na adoção de políticas públicas, orçamentos e gastos mais transparentes, a corrupção permanece, sem que haja qualquer mudança no que diz respeito à responsabilização dos agentes públicos e privados perante a sociedade. No âmbito do projeto de reforma do Estado, o conceito de transparência surgiu como proposição universal, sem que se leve em conta realidades culturais, políticas e institucionais distintas. E, no caso brasileiro, como destaca Abrucio, ela pouco avançou no que diz respeito à sua eficiência. Tendo em vista estas mudanças institucionais, discutimos, na seção seguinte, a percepção dos burocratas da linha de frente (street-level bureaucrats) sobre o controle da corrupção.

\section{O QUE DIZEM OS BUROCRATAS AO NÍVEL DA RUA?}

A experiência brasileira recente com o tema da corrupção revela um paradoxo, quando se discute o controle. As instituições de controle no Brasil foram aprimoradas e efetivaram-se instrumentos de transparência da gestão, mas a corrupção permanece como prática recorrente (Filgueiras e Avritzer, 2010). O Tribunal de Contas da União tem uma margem razoável de autonomia institucional para o exercício do controle externo (Loureiro et al., 2009). O Ministério Público e a Polícia Federal exercem suas atividades investigativas e, no âmbito do Poder Executivo, foi criada a Controladoria Geral da União, instituição à qual coube centralizar o controle de gestão, de auditoria de contas, correição e prevenção da corrupção. Pode-se dizer que, no Brasil depois de 1988, configurou-se uma política pública de controle e combate à corrupção. Se associada a princípios como responsabilidade fiscal e controle de gastos, percebe-se um avanço da gestão, apesar de a corrupção ser uma prática ainda comum e recorrente.

Apesar do avanço institucional, a corrupção permanece como uma prática corriqueira na esfera pública. Ou seja, do avanço institucional realizado no Brasil, não se seguiu uma percepção da diminuição da corrupção. Do ponto de vista institucional, isto ocorre porque as reformas privilegiaram o fortalecimento das instituições de controle buro- 
crático em detrimento das instituições de controle judicial e de controle público não-estatal, além de não promover uma integração sistêmica que lhes permitisse maior efetividade do controle da corrupção (Filgueiras e Avritzer, 2010). A percepção da sanção no Brasil é prejudicada porquanto haja, de acordo com Taylor e Buranelli (2007), uma disjunção das instituições de controle. Isso fica claro no modo como o cidadão percebe o avanço da corrupção no Brasil:

Tabela 1

Evolução da Corrupção nos Últimos Cinco Anos

(Brasil, 2009) $^{1}$

\begin{tabular}{l|c}
\hline Categoria & Percentual \\
\hline Aumentou muito & 39,0 \\
Aumentou um pouco & 33,0 \\
Não aumentou, nem diminuiu & 19,0 \\
Diminuiu um pouco & 5,0 \\
Diminuiu muito & 1,0 \\
NS / NR & 3,0 \\
\hline Total & $\mathbf{1 0 0 , 0}$ \\
\hline
\end{tabular}

Fonte: Centro de Referência do Interesse Público, 2009.

O resultado desse padrão de mudança institucional foi reforçar o controle burocrático no contexto das reformas administrativas - especialmente no que diz respeito aos processos de auditorias de contas - e aprimorar os instrumentos de transparência de contas e processos. Contudo, estas mudanças não foram acompanhadas de mudanças no controle judicial, tendo em vista códigos de processo ultrapassados, baixa efetividade das sanções administrativas e baixa efetividade das sanções penais (Arantes, 2010). O resultado é que a corrupção se tornou mais transparente no Brasil, especialmente com a atuação da Polícia Federal. Esse melhor desvelamento das mazelas administrativas no Brasil impacta negativamente a opinião pública, alimenta uma sensação de impunidade e contribui para um baixo apoio político ao Estado e suas instituições.

As reformas gerenciais no Brasil priorizaram os altos burocratas. A própria literatura especializada toma a relação entre a burocracia e a política do prisma do alto escalão e de seu poder decisório. Como observam Loureiro, Olivieri e Martes (2010), a literatura brasileira sobre burocracia privilegia a questão do processo decisório das políticas pú- 
blicas, tendo em vista duas vertentes analíticas: 1) a vertente marxista, que aborda a burocracia do ângulo de classe do Estado; 2) a vertente neoinstitucionalista, que aborda a burocracia do ângulo dos dilemas de organização institucional. Como as autoras apontam, é necessário esclarecer o conceito de burocracia, que se refere aos:

ocupantes dos cargos de alto escalão ou de direção dos órgãos da administração direta e indireta do Poder Executivo. Eles podem ser tanto funcionários públicos de carreira (admitidos por concurso público) quanto profissionais de fora do setor público (recrutados em empresas privadas, entidades não estatais, como universidades ou centros de pesquisa, bem como em sindicatos e organizações da sociedade civil) que exercem temporariamente atividades de direção nos órgãos governamentais. (Loureiro, Olivieri e Martes, 2010:79)

Ao contrário do que a literatura sobre burocracia no Brasil postula, acreditamos que observar a percepção dos burocratas da linha de frente do serviço público sobre as instituições de controle possa contribuir para desvendar o paradoxo entre ampliação do controle e continuidade da percepção negativa dos cidadãos sobre a corrupção. Como apontam Hupe e Hill (2007), é importante observar o comportamento dos burocratas ao nível da rua, porquanto eles se relacionam diretamente com o cidadão, o que torna central sua ação para a percepção da accountability. Como a reforma gerencial concentrou as mudanças no alto escalão da burocracia, o a primoramento do controle não chegou ao nível da rua, modificando muito pouco a percepção do cidadão sobre a performance das políticas e, por sua vez, sobre a corrupção. A corrupção é mais controlada e desvelada, mas isto não significa que o controle e a transparência modificaram as práticas da linha de frente da burocracia, criando uma percepção negativa dos cidadãos quanto ao Estado brasileiro. $\mathrm{O}$ avanço das reformas gerenciais não privilegiou os burocratas da linha de frente, fazendo com que práticas como suborno e como propina continuem sendo reproduzidas, apesar dos avanços gerenciais.

Os dados que seguem abaixo se referem a uma pesquisa de survey com servidores públicos federais, civis, ativos, do Poder Executivo, realizada no ano de 2010. Nessa pesquisa, perquirimos a percepção deles sobre as instituições de controle, sobre práticas que podem aprimorar o controle e questões gerais referentes a práticas que podem ocorrer no serviço público e serem interpretadas como corrupção (Apêndice 2). De imediato, é preciso notar o modo como a percepção de servidores 
públicos e de cidadãos comuns difere quanto a questões de cultura política e de percepção da corrupção. A burocracia é um campo especializado e que tem práticas próprias baseadas em uma linguagem comum ao campo (Bourdieu, 2005).

A amostra, em termos de funções, perfaz o fato de que maioria dos servidores públicos entrevistados ocupa postos sem função hierárquica. Em seguida, a parecem alguns chefes, comissionados e coordenadores. As funções que menos aparecem são os assessores (apenas cinco) e os supervisores (apenas oito). A amostra buscou os servidores da linha de frente da burocracia, nos diferentes estados da Federação e em diferentes posições no âmbito da hierarquia.

Tabela 2

Distribuição de Servidores por Funções

(Brasil, 2010)

\begin{tabular}{l|c|c|c|c}
\hline \multicolumn{1}{c|}{ Função } & $\begin{array}{c}\text { Administração } \\
\text { Direta }\end{array}$ & Autarquias & Fundações & Total \\
\hline Assessores & 4 & 1 & 0 & 5 \\
Assistentes & 8 & 4 & 5 & 17 \\
Chefes & 31 & 27 & 20 & 78 \\
Coordenadores & 2 & 15 & 8 & 25 \\
Comissionados & 11 & 4 & 11 & 26 \\
Diretores & 1 & 12 & 2 & 15 \\
Gerentes & 1 & 6 & 5 & 12 \\
Supervisores & 0 & 0 & 8 & 8 \\
Outros & 2 & 16 & 3 & 21 \\
Servidores sem função hierárquica & 410 & 413 & 162 & 985 \\
\hline Total & $\mathbf{4 7 8}$ & $\mathbf{4 9 8}$ & $\mathbf{2 2 4}$ & $\mathbf{1 . 1 9 2}$ \\
\hline
\end{tabular}

Fonte: Centro de Referência do Interesse Público, 2010.

Na Tabela 3, apresentamos a distribuição pelos cargos ocupados pelos servidores entrevistados. No que diz respeito ao controle por cargos, o objetivo era apreender a pluralidade de atividades exercidas pelos servidores federais civis. Os cargos que mais apareceram foram: agente administrativo (145), técnico (120), assistente (96), analista (88), médico (81) e professor de terceiro grau (71).

De imediato, é importante observar que a burocracia significa um campo de atividade profissional especializada e fortemente hierarquizada, baseada em uma concepção formal e distinta do interesse público. 
Tabela 3

Servidores por Cargos

(Brasil, 2010)

\begin{tabular}{|c|c|c|c|}
\hline Cargos & Administração Direta & Autarquias & Fundações \\
\hline Administradores & 2 & 0 & 2 \\
\hline Advogados & 1 & 0 & 0 \\
\hline Agente administrativo & 117 & 12 & 16 \\
\hline Analistas & 38 & 40 & 10 \\
\hline Arquivistas & 2 & 0 & 0 \\
\hline Artífices & 3 & 0 & 2 \\
\hline Assistentes & 4 & 57 & 35 \\
\hline Assistentes sociais & 2 & 0 & 0 \\
\hline Auditores & 44 & 0 & 0 \\
\hline Auxiliares & 30 & 19 & 13 \\
\hline Farmacêuticos & 2 & 2 & 2 \\
\hline Procuradores & 21 & 0 & 0 \\
\hline Contadores & 2 & 4 & 0 \\
\hline Datilógrafos & 5 & 12 & 0 \\
\hline Defensores & 1 & 0 & 0 \\
\hline Delegados da Polícia Federal & 8 & 0 & 0 \\
\hline Digitadores & 1 & 0 & 0 \\
\hline Economistas & 1 & 1 & 1 \\
\hline Enfermeiros & 10 & 6 & 7 \\
\hline Engenheiros & 1 & 8 & 2 \\
\hline Escrivães da Polícia Federal & 9 & 0 & 0 \\
\hline Especialista em políticas públicas & 2 & 0 & 0 \\
\hline Policiais rodoviários & 35 & 0 & 0 \\
\hline Telefonistas & 3 & 0 & 1 \\
\hline Fiscais & 13 & 0 & 0 \\
\hline Médicos & 51 & 22 & 8 \\
\hline Motoristas & 4 & 5 & 1 \\
\hline Peritos & 1 & 0 & 0 \\
\hline Técnicos & 30 & 33 & 57 \\
\hline Pesquisadores & 5 & 3 & 5 \\
\hline Professor de ensino básico & 0 & 39 & 1 \\
\hline Professor de $3^{\circ}$ grau & 0 & 44 & 27 \\
\hline Pedagogos & 0 & 4 & 0 \\
\hline Bibliotecários & 0 & 4 & 0 \\
\hline Secretários & 0 & 2 & 1 \\
\hline Especialistas & 0 & 11 & 0 \\
\hline Sem especificação & 19 & 19 & 5 \\
\hline Outros & 11 & 151 & 28 \\
\hline Total & 478 & 498 & 224 \\
\hline
\end{tabular}

Fonte: Centro de Referência do Interesse Público, 2010. 
Esta proposição fica clara quando comparamos noções de interesse público de burocratas e de cidadãos. Para comparar as respostas dos nossos burocratas ao nível da rua com as dos cidadãos brasileiros, recorremos a outro survey realizado pelo Centro de Referência do Interesse Público, que investigou a percepção dos brasileiros sobre corrupção e interesse público.

Pode-se notar pela Tabela 4 uma disjunção na percepção entre servidores e cidadãos sobre o que seria o interesse público. Enquanto para os cidadãos a resposta mais acionada foi a de que o interesse da maioria sempre significa interesse público, os servidores possuem uma visão mais ampla deste conceito, segundo a qual nem sempre o interesse público é o interesse da maioria, e que o interesse da maioria não significa interesse público. Isto é, para os servidores, o interesse público não seria tanto uma questão de quantidade de pessoas (opinião do maior número de pessoas), podendo ter mais a ver com o que é de todas as pessoas, o que todos têm em comum, não somente uma mera agregação/somatório de opiniões. Desta forma, o que é interesse público para os cidadãos é o que a maioria deseja, já para os servidores essa associação nem sempre é válida.

Tabela 4

Relação entre Interesse Público e Interesse da Maioria - Cidadãos e Servidores Públicos (Brasil, 2010)

\begin{tabular}{l|c|c}
\hline Categorias & Cidadãos & Servidores \\
\hline Sim, o interesse da maioria significa interesse público & $58,0 \%$ & $16,8 \%$ \\
Nem sempre o interesse da maioria significa interesse público & $27,0 \%$ & $62,0 \%$ \\
Não, o interesse da maioria não significa interesse público & $9,0 \%$ & $20,3 \%$ \\
NS / NR & $6,0 \%$ & $0,5 \%$ \\
\hline Total & $\mathbf{1 0 0 , 0 \%}$ & $\mathbf{1 0 0 , 0 \%}$ \\
\hline
\end{tabular}

Fonte: Centro de Referência do Interesse Público, 2010.

Da mesma forma, na Tabela 5 percebe-se também uma disjunção quando se questiona servidores e cidadãos quanto à confiança no alto escalão do Governo Federal. Por estes dados nota-se que os servidores públicos têm uma percepção mais otimista em relação à participação do alto escalão do governo em esquemas de corrupção, ou seja, confiam mais nos membros do alto escalão. Enquanto os cidadãos acreditam mais que a maioria destes ocupantes de cargos no alto escalão do governo aceitaria entrar em esquemas de corrupção (resposta acionada 
por $46 \%$ dos cidadãos), a opinião dos servidores vai na direção oposta: apenas uma minoria destes ocupantes aceitaria entrar no esquema (resposta acionada por $40 \%$ dos servidores). Aqui é possível perceber o paradoxo de que falávamos acima, entre a ampliação do controle que ocorreu no Brasil e a percepção negativa dos cidadãos brasileiros sobre a corrupção, pois, de acordo com os dados, os cidadãos ainda têm uma opinião negativa acerca do envolvimento de funcionários públicos de altos cargos com a corrupção. Assim, mais uma vez percebe-se que as opiniões dos cidadãos em geral diferem daquelas dos servidores públicos. Isto demonstra que quem está dentro da burocracia federal tem uma percepção diferente do senso-comum formulada pela percepção dos cidadãos a respeito do significado do interesse público e da aceitação da corrupção. Os servidores teriam uma cultura própria, constituiriam um campo próprio.

\section{Tabela 5}

Participação de Membros do Alto Escalão do Governo em Esquemas de Corrupção - Servidores e Cidadãos

(Brasil, 2010)

\begin{tabular}{|c|c|c|}
\hline Categorias & Cidadãos & Servidores \\
\hline $\begin{array}{l}\text { Apenas uma minoria aceitaria entrar em um esquema de cor- } \\
\text { rupção }\end{array}$ & $15,0 \%$ & $40,3 \%$ \\
\hline $\begin{array}{l}\text { Mais ou menos a metade destas pessoas aceitaria entrar em } \\
\text { um esquema de corrupção }\end{array}$ & $34,0 \%$ & $28,7 \%$ \\
\hline $\begin{array}{l}\text { A maioria destas pessoas aceitaria entrar no esquema de cor- } \\
\text { rupção }\end{array}$ & $46,0 \%$ & $29,4 \%$ \\
\hline NS / NR & $5,0 \%$ & $1,6 \%$ \\
\hline Total & $100,0 \%$ & $100,0 \%$ \\
\hline
\end{tabular}

Fonte: Centro de Referência do Interesse Público, 2010.

Depreende-se das tabelas acima que as opiniões de servidores frente às opiniões de cidadãos são muito diferenciadas e não podem ser mensuradas por se tratarem de campos distintos. Após essa breve comparação entre a opinião de cidadãos e de servidores, que nos serviu para demonstrar que os servidores públicos da linha de frente constituem um campo próprio, com opiniões diferentes daquelas dos cidadãos, com uma percepção mais ampla do interesse público e mais otimistas em relação aos ocupantes de cargos do alto escalão, partimos para uma breve descrição destes servidores públicos federais que responderam ao já referido survey. Com essa descrição e com as opiniões dos servidores 
públicos da linha de frente, queremos compreender quem são esses servidores e quais são as suas opiniões. Apenas a partir disso poderemos interpretar a percepção deles sobre corrupção.

No âmbito da amostra formulada, 69\% destes servidores atuam há mais de 15 anos no serviço público federal ( $14 \%$ atua de 15 a 20 anos, e $55 \%$ há mais de 20 anos), o que demonstra que os nossos respondentes, em sua maioria, conhecem bem e já estão familiarizados com o que ocorre neste campo. A maioria destes servidores que compuseram a amostra (85\%) ingressou no serviço público federal por meio de concurso. Aqueles poucos advindos da efetivação são os remanescentes do período anterior à Constituição de 1988, quando quem estava dentro do serviço público foi efetivado e passou a fazer parte da administração pública. Em termos de escolaridade, a maioria dos entrevistados possui ensino superior completo $(43,5 \%)$. Em seguida aparecem os servidores com especialização $(14,2 \%)$, doutorado/pós-doutorado $(12,9 \%)$ e segundo grau completo $(12,6 \%)$. Os níveis de escolaridade menos recorrentes entre os entrevistados são segundo grau incompleto $(5,5 \%)$, mestrado incompleto $(1,1 \%)$ e doutorado incompleto $(1,7 \%)$.

Além dessa caracterização sociodemográfica, os servidores foram interpelados a avaliar diferentes questões organizacionais do serviço público federal. Quando chamados a se posicionar sobre a qualificação dos servidores e os planos de carreira, os entrevistados tenderam a ser mais pessimistas em relação aos planos de carreira (apesar de a maioria concordar que os planos são bons, houve um percentual significativo que declarou que estes são péssimos/ruins - 25\%), e, por outro lado, avaliam mais positivamente a qualificação dos servidores ( $50 \%$ acredita que a qualificação é boa e $21,7 \%$ ótima).

Além de questões que dizem respeito aos planos de carreira e à qualificação dos servidores, eles foram questionados sobre processos de treinamento nas leis gerais e específicas que regulam a atuação dos servidores (procedimentos), se eles tiveram algum tipo de formação ética e se as leis são igualmente aplicadas no cotidiano do serviço público. Estas três ordens de questões interpelam o treinamento dos servidores e o universalismo dos procedimentos que caracteriza a burocracia. A Tabela 7 aponta para um grave problema: de acordo com os servidores entrevistados, as normas do serviço público não são igualmente aplicadas no cotidiano dos órgãos públicos federais, isto é, não haveria universalismo de procedimentos, que é um dos pilares básicos das bu- 
Tabela 6

Avaliação da Qualificação dos Servidores para o Exercício da Função e Avaliação dos Planos de Carreira

(Brasil, 2010)

\begin{tabular}{l|c|c}
\hline Categoria & $\begin{array}{c}\text { Avaliação da Qualificação dos Servidores } \\
\text { para o Desempenho das Funções }\end{array}$ & $\begin{array}{c}\text { Avaliação dos Planos de } \\
\text { Carreira }\end{array}$ \\
\hline Péssimo & $3,1 \%$ & $13,9 \%$ \\
Ruim & $2,1 \%$ & $12,4 \%$ \\
Regular & $23,0 \%$ & $32,5 \%$ \\
Bom & $50,1 \%$ & $36,0 \%$ \\
Ótimo & $21,7 \%$ & $5,1 \%$ \\
\hline Total & $\mathbf{1 0 0 , 0 \%}$ & $\mathbf{1 0 0 , 0 \%}$ \\
\hline
\end{tabular}

Fonte: Centro de Referência do Interesse Público, 2010.

rocracias. Se as normas não são igualmente aplicadas, significa que alguns são favorecidos, o que abre espaço para práticas corruptas. Ainda em relação a esta Tabela, percebe-se um alto percentual de servidores que não receberam algum tipo de treinamento - $42 \%$ não receberam formação sobre leis, e 50\% não receberam formação ética.

Tabela 7

Formação Ética, Treinamento e

Universalismo dos Procedimentos Burocráticos, Brasil, 2010

\begin{tabular}{l|c|c}
\hline Categorias & Sim & Não \\
\hline $\begin{array}{l}\text { Considera que as normas do serviço público são igual- } \\
\text { mente aplicadas no cotidiano do seu órgão? }\end{array}$ & $38,1 \%$ & $61,9 \%$ \\
$\begin{array}{l}\text { Recebeu alguma formação sobre as leis gerais e específicas } \\
\text { que regulam o serviço público? }\end{array}$ & $57,3 \%$ & $42,7 \%$ \\
Recebeu alguma formação sobre ética no serviço público? & $49,8 \%$ & $50,2 \%$ \\
\hline
\end{tabular}

Fonte: Centro de Referência do Interesse Público, 2010.

Nas respostas específicas sobre práticas de corrupção dentro da administração pública federal, 34,8\% dos entrevistados percebem que a cobrança de propina é muito frequente / frequente, enquanto este percentual é menor no que se refere às práticas de suborno, pois apenas $17 \%$ percebe a tentativa de suborno como muito frequente/frequente. $\mathrm{Ou}$ seja, a ação que parte dos próprios servidores - cobrar propina - ocorreria em uma frequência maior do que aquela que parte de terceiros tentativa de suborno. Ressaltamos aqui que a prática do suborno e da propina são aquelas típicas dos burocratas da linha de frente, que nor- 
malmente referem-se a presentes e rendas que caracterizam a pequena corrupção. Propina e suborno, portanto, são medidas da corruptibilidade dos servidores públicos frente à sua relação direta com os cidadãos e o cumprimento das regras e procedimentos que regulam a atividade burocrática (Miller, 2006). Neste caso, suborno e propina referem-se a uma patologia derivada do uso indevido da discricionariedade.

Tabela 8

Frequência da Tentativa de Suborno e da Cobrança de Propina na Administração Pública Federal

(Brasil, 2010)

\begin{tabular}{l|c|c}
\hline Categorias & $\begin{array}{c}\text { Frequência da Cobrança } \\
\text { de Propina }\end{array}$ & $\begin{array}{c}\text { Frequência da Tentativa } \\
\text { de Suborno }\end{array}$ \\
\hline Muito frequente & $10,0 \%$ & $6,0 \%$ \\
Frequente & $24,8 \%$ & $11,7 \%$ \\
Pouco frequente & $44,7 \%$ & $43,3 \%$ \\
Nada frequente & $20,4 \%$ & $39,1 \%$ \\
\hline Total & $\mathbf{1 0 0 , 0 \%}$ & $\mathbf{1 0 0 , 0 \%}$ \\
\hline
\end{tabular}

Fonte: Centro de Referência do Interesse Público, 2010.

Mais do que buscar a frequência da corrupção, a pesquisa também questionou quais seriam, na opinião dos servidores, os principais elementos que explicam a corrupção. Ou seja, dado que a corrupção existe, qual seria a sua causa? As respostas mais acionadas pelos servidores são as que tratam da impunidade e das falhas do Poder Judiciário $(32,2 \%)$ e da cultura brasileira $(20 \%)$, relacionada às práticas da malandragem e do jeitinho. Desta forma, de acordo com essas respostas, os principais fatores que explicariam a corrupção não dizem respeito à organização ou normas da administração pública em si, estando relacionados com as falhas percebidas do sistema judicial e com a cultura brasileira em geral.

Tendo em mente esse quadro sobre a percepção dos servidores da linha de frente - que nos indica que a corrupção ocorre na burocracia do nível da rua mediante práticas de propina e suborno, que o universalismo de procedimentos não é recorrente, que falta treinamento aos servidores e que as causas disto devem ser buscadas em falhas no judiciário e na cultura política - nos questionamos se existiria algum padrão na relação entre essas variáveis descritas. Assim, a partir destas variáveis descritas anteriormente, foi feita uma análise fatorial, com extração 
Tabela 9

Principais Fatores que Explicam a Corrupção (\%)

Brasil, 2010

\begin{tabular}{l|c}
\hline Categoria & Percentual \\
\hline Impunidade e um sistema judicial ineficiente & 32,2 \\
A cultura da sociedade brasileira, a falta de ética, o jeitinho & 20,0 \\
Ganância e desejos de obter ganhos, por parte dos servidores & 10,4 \\
Falta de fiscalização e transparência & 8,9 \\
Salários muito baixos e um plano de carreira mais robusto & 8,6 \\
Excesso de burocracia, normas e procedimentos & 5,9 \\
Interferência inadequada da política nas atividades da burocracia & 4,0 \\
Abuso de autoridade por parte dos superiores hierárquicos & 2,9 \\
Excesso de cargos de confiança na administração pública & 1,8 \\
Falta de concursos públicos & 1,6 \\
Corporativismo no setor público & 1,4 \\
Falta de leis mais rígidas para o exercício do controle da corrupção & 0,9 \\
Nepotismo, paternalismo e indicações indevidas & 0,8 \\
Falta de controle social das políticas públicas & 0,5 \\
A regra de estabilidade funcional & 0,1 \\
\hline Total & $\mathbf{1 0 0 , 0}$ \\
\hline
\end{tabular}

Fonte: Centro de Referência do Interesse Público, 2010.

dos componentes principais, a fim de estabelecer se existiria um padrão na relação entre estas variáveis. O objetivo desta técnica é estabelecer a dimensionalidade dos dados, identificando os fatores latentes que representam as interações do conjunto das variáveis. Buscou-se definir quais seriam os fatores associados com as respostas dos servidores sobre corrupção. Este teste serviu para averiguar o sentido de agregação de variáveis relativas a diferentes formas de perceber a corrupção na administração pública federal, conforme exposto na Tabela 10 a seguir.

O modelo desta análise fatorial incluiu as variáveis categóricas relativas a aspectos socioeconômicos dos servidores (renda e escolaridade), do próprio serviço (tempo de atuação e forma de ingresso), avaliações feitas pelos servidores sobre qualificação e planos de carreira, e também variáveis que dizem da formação recebida pelos servidores e das suas opiniões sobre a incidência de corrupção. Com capacidade de explicação da variância de 59,44\%, a matriz resultante retornou cinco fatores latentes. O primeiro fator foi formado pelas variáveis de tempo 
Tabela 10

Análise Fatorial dos Componentes Principais

\begin{tabular}{l|c|c|c|c|c}
\hline Variáveis & \multicolumn{3}{c}{ Componentes } \\
\hline Tempo de atuação dos servidores & $\mathbf{0 , 7 0 4}$ & & & & \\
\hline Forma de ingresso no Serviço Público Federal & $\mathbf{0 , 8 3 7}$ & & & & \\
\hline Escolaridade dos servidores & & $\mathbf{0 , 6 8 8}$ & & \\
\hline Renda familiar dos servidores & & $\mathbf{0 , 7 9 3}$ & & & \\
\hline $\begin{array}{l}\text { Avaliação da qualificação dos servidores para o } \\
\text { exercício das funções }\end{array}$ & & 0,362 & & & \\
\hline $\begin{array}{l}\text { Avaliação dos planos de carreira do órgão quanto ao } \\
\text { nível de exigência técnica ou responsabilidade fun- } \\
\text { cional }\end{array}$ & & 0,340 & & & \\
\hline $\begin{array}{l}\text { Considera que as normas da administração pública } \\
\text { são igualmente aplicadas no cotidiano dos órgãos }\end{array}$ & & & $\mathbf{0 , 5 0 2}$ & & \\
\hline Recebeu alguma formação sobre ética & & & & $\mathbf{0 , 8 2 0}$ & \\
\hline $\begin{array}{l}\text { Recebeu alguma formação sobre as leis gerais e espe- } \\
\text { cíficas que regulam o exercício de sua função }\end{array}$ & & & & $\mathbf{0 , 8 2 0}$ & \\
\hline $\begin{array}{l}\text { Frequência da tentativa de suborno } \\
\text { Frequência da cobrança de propina }\end{array}$ & & & $\mathbf{0 , 7 4 8}$ & & \\
\hline $\begin{array}{l}\text { ção pública federal } \\
\text { Fator que contribui para a corrupção na administra- }\end{array}$ & & & $\mathbf{0 , 6 6 3}$ & & \\
\hline
\end{tabular}

Fonte: Centro de Referência do Interesse Público, 2010.

Nota: Análise fatorial com método de extração dos componentes principais, com método de rotação Varimax com normalização Kaiser. As variáveis cujos pesos são maiores do que 0,5 estão grafadas em negrito.

de atuação e forma de ingresso (ambas com pesos elevados, entre 0,7 e $0,8)$. O segundo fator agrupou as variáveis socioeconômicas de renda e escolaridade (com peso entre 0,6 e 0,7) e aquelas referentes às avaliações dos servidores quanto à qualificação e os planos de carreira (mas, neste caso, com pesos menores, em torno de 0,3 ). O terceiro fator revelou a agregação de variáveis como opinião sobre igualdade na aplicação das normas (com peso de 0,5 ) e as percepções acerca da corrupção no serviço público federal (com peso em torno de 0,6 e 0,7 ). O quarto fator mostrou que as variáveis relativas à formação dos servidores sobre ética e leis estão juntas (com peso elevado de 0,8 ). Finalmente, o último fator foi formado por uma variável: qual o fator que mais contribui para a corrupção (com o peso mais alto encontrado, de 0,95 ).

Algumas observações importantes derivam da análise fatorial apresentada. Em primeiro lugar, o tempo de atuação dos entrevistados se 
agrega somente com a variável forma de ingresso. A união destas duas variáveis indica a existência de um fator que podemos chamar de "socialização interna", que quer dizer que a forma como o servidor entra no serviço público e a duração da sua carreira estão fortemente relacionadas.

No segundo fator, chama a atenção o fato de que as variáveis socioeconômicas aparecem agregadas a variáveis avaliativas dos servidores, apesar de estas últimas apresentarem pesos menores. Neste segundo fator, observa-se que as variáveis relacionadas è estrutura da gestão de pessoal do Governo Federal se associam. Pode-se entender a agregação de variáveis tão diferentes se fizermos um teste de associação (qui-quadrado). Por meio deste teste é possível verificar que a renda e a escolaridade estão associadas com a avaliação que os servidores fazem da qualificação e dos planos de carreira ${ }^{2}$.

O terceiro fator, por nós chamado de "Universalismo de Procedimentos e Corrupção", vale a pena ser destacado. Ele nos mostra que a opinião dos entrevistados sobre a corrupção (a frequência do suborno e da propina) está agregada com a opinião dos mesmos sobre a igualdade na aplicação das normas. Como visto na descrição destas variáveis, a maioria dos entrevistados acredita que as normas não são igualmente aplicadas, isto é, não existiria universalismo de procedimentos, o que estaria ligado à percepção deles sobre a presença e a frequência da corrupção. Isto é, a percepção dos servidores sobre a frequência da propina e do suborno em seus órgãos está relacionada a uma percepção fortemente negativa da não-universalidade dos procedimentos na administração pública brasileira. A visão negativa que os servidores constroem sobre a aplicação das normas levaria a uma visão negativa da frequência do suborno e da propina, o que também pode ser demonstrado com testes de associação entre estas variáveis ${ }^{3}$. O que caracteriza a percepção negativa dos servidores sobre a cobrança de suborno e de propina na administração pública está relacionado com uma percepção de baixa universalidade dos procedimentos, o que permite depreender que apesar dos avanços na dimensão da gerência e do alto escalão da burocracia, ainda há muito que avançar no serviço público brasileiro, especialmente no que diz respeito aos servidores da linha de frente. Isto fica claro no modo como as variáveis referentes ao treinamento agregam-se distintamente da questão socioeconômica dos servidores. 
E, finalmente, o quinto fator nos revela que a variável sobre as "Causas da corrupção" se encontra sozinha, pois não aparece nenhuma outra variável agregada a ela. Importante observar a ordem dos elementos manifestados pelos servidores que explicariam a corrupção. Para eles, a corrupção é explicada externamente à administração pública, sendo atribuída a uma cultura política pouco desenvolvida, alicerçada no jeitinho e por uma percepção de inefetividade da atuação do sistema judicial no combate à corrupção. Isto demonstra que as respostas dos servidores sobre as causas da corrupção não estão agregadas com a condição socioeconômica, com a socialização interna dentro do serviço público, com o treinamento recebido e, vale ressaltar, com o universalismo de procedimentos - a causa da corrupção não estaria no fato de as normas não serem igualmente aplicadas, nem na frequência da propina ou do suborno. A visão dos servidores sobre as causas da corrupção não interage com outros fatores. Ou seja, não depende nem de sua condição socioeconômica, nem do treinamento nos procedimentos e nos valores da ética pública. Ao atribuírem a explicação da corrupção a fatores externos à administração pública, os servidores públicos revelam ou uma posição cínica em relação à corruptibilidade do sistema administrativo do Estado brasileiro, ou uma posição de desconhecimento da corrupção.

O que é importante frisar é o fato de os servidores associarem as práticas de suborno e de propina com a baixa percepção sobre o universalismo dos procedimentos, o que mantém a agenda de reforma administrativa ainda vigente no Brasil, uma vez que ela ainda não tenha chegado aos servidores da linha de frente das atividades burocráticas. Com isso, corroboramos nossa hipótese apresentada no início do artigo: as reformas gerenciais não chegaram até a ponta do serviço público. $\mathrm{O}$ campo burocrático no Brasil ainda toma a propina e o suborno como práticas corriqueiras e organiza-se em torno de uma baixa presença de regras universais que, associada com a discricionariedade, cria condições para que a corrupção floresça e se mantenha como prática corriqueira na administração pública.

\section{CONSIDERAÇÕES FINAIS}

Os estudos sobre burocracia no Brasil desvelaram o papel dos burocratas no processo decisório das políticas públicas, observando a centralidade de sua atuação no contexto das transformações gerenciais da década de 1990 (Loureiro et alii, 2010). Contudo, pouca atenção tem sido 
dada, no caso do Brasil, ao papel dos burocratas da linha de frente, especialmente responsáveis pela implementação das políticas públicas. A pouca atenção da literatura especializada a estes burocratas revela que ainda há uma enorme agenda de pesquisas a cobrir temas relacionados à questão da capacidade de gestão, às especificidades do treinamento e à redução da margem de presença da corrupção no cotidiano da administração pública brasileira, especialmente no que se refere ao suborno e à propina. Além das questões relativas a este estudo, esta problematização a respeito das burocracias da linha de frente deve ser considerada nos processos de implementação e avaliação das políticas públicas, tendo em vista os padrões de eficiência publicamente pactuados. Acreditamos que este deve ser um quadro de pesquisas futuras, que procurem perceber o papel dos burocratas da linha de frente no debate sobre reforma, gestão por resultados, eficiência e melhoria institucional da gestão pública.

No que tange a este estudo, podemos interpelar que a razão pela qual o avanço das instituições de controle e dos processos de gestão pública não foi seguido de uma melhora nos padrões de percepção da corrupção é derivada, ainda, de um déficit de accountability no âmbito da gestão pública brasileira, que, neste caso, não pode ser confundido com um déficit de transparência. Houve melhorias institucionais na gestão pública brasileira à medida que a transparência foi sendo aprimorada. A corrupção hoje, no Brasil, é transparente ao público. Entretanto, a corrupção que hoje transparece não é punida, não permitindo um processo substancial de responsabilização dos agentes públicos. A corrupção continua bastante percebida por parte da opinião pública, e isto tem impactado negativamente a cultura política democrática e a legitimidade do Estado brasileiro. Apesar das inovações gerenciais, a corrupção continua como uma prática corriqueira, pautando negativamente a opinião pública brasileira.

A razão explicativa que abordamos neste estudo está no fato de as inovações gerenciais não terem sido compatibilizadas com inovações na posição e nas carreiras dos servidores da linha de frente da administração pública. Isto faz com que comportamentos como cobrança de propina e aceitação de suborno continuem como práticas cotidianas no âmbito de organizações, as quais carecem de regras e procedimentos mais claros e universais. Os dados de nossa pesquisa revelam que a continuidade da agenda de reformas administrativas deve observar a posição dos burocratas da linha de frente, com o objetivo de aprimorar 
os mecanismos de gestão e permitir o devido uso da margem de discricionariedade legalmente garantida. Isso significa aprimorar os mecanismos de treinamento nos valores da ética pública e nos procedimentos que regulam as atividades burocráticas especializadas e cotidianas. Neste sentido, a nosso ver, é fundamental valorizar e assegurar mecanismos de mudança institucional que aprimorem o universalismo dos procedimentos, especialmente no que diz respeito à aplicação de regras institucionais na relação direta com os cidadãos. Seguindo a tese de Hupe e Hill (2007), é primordial valorizar e aprimorar a atuação dos burocratas da linha de frente no âmbito do Estado brasileiro, tendo em vista um projeto de mudança a respeito da percepção da accountability. O caso brasileiro revela o modo como o aprimoramento institucional das instituições de accountability não foi seguido de sua percepção positiva. Nesse caso, o aprimoramento da gestão pública no Brasil, com o reforço da transparência, não foi seguido de uma diminuição na percepção da corrupção, por parte da cidadania.

Sem reforçar o valor do universalismo dos procedimentos, tendo em vista o aprimoramento do treinamento de servidores nos valores da ética pública e nas regras rotineiras que regulam o serviço público, pouco avançaremos na consolidação de padrões de gestão que signifiquem o aprimoramento da accountability e, por sua vez, a valorização do interesse público como indisponível aos interesses privados. Ou seja, sem que o Estado brasileiro valorize a atuação dos servidores da linha de frente, pouco avançará na sua democratização e na consolidação dos mecanismos de controle como fundamentais a uma concepção republicana dos valores públicos.

(Recebido em março de 2011)

(Versão definitiva em agosto de 2011) 


\section{NOTAS}

1. A pesquisa com cidadãos refere-se a um survey nacional de opinião realizado pelo Centro de Referência do Interesse Público. Para mais detalhes, conferir o Apêndice 1.

2. A escolaridade está associada com a opinião sobre a qualificação dos servidores: aqueles que possuem até ensino superior completo tendem a avaliar melhor a qualificação dos servidores (54\% dizem que é boa). Os que possuem níveis de escolaridade mais altos (pós-graduação) tendem a não avaliar tão bem a qualificação dos servidores ( $p$ valor $=0,036$ ). A escolaridade também está associada com a avaliação dos planos de carreira, mas aqui a relação é inversa: quanto maior o nível de escolaridade, melhor a avaliação dos planos de carreira ( $\mathrm{p}$ valor $=0,031$ ). A renda também está associada com a avaliação da qualificação: quem recebe menos tende a avaliar a qualificação dos servidores como regular/boa, enquanto os mais ricos a avaliam de forma melhor, como boa/ótima.

3. O teste de qui-quadrado revelou que quem considera as normas igualmente aplicadas tem uma visão mais positiva, acredita mais que o suborno e a propina são nada freqüentes. Já quem não considera acredita mais que o suborno e a propina são pouco freqüentes e tem percentuais maiores nas opções freqüente e muito freqüente ( $p$ valor para os dois testes $=0,0001$ ). 


\section{REFERÊNCIAS BIBLIOGRÁFICAS}

ABRUCIO, Fernando Luiz. (2007), “Trajetória Recente da Gestão Pública Brasileira: Um Balanço Crítico e a Renovação da Agenda de Reformas". Revista de Administração Pública, vol. 41, edição especial comemorativa, pp. 67-86.

ANECHIARICO, Frank e JACOBS, James. (1996), The Pursuit of Absolute Integrity, How Corruption Control Makes Government Ineffective. Chicago, The University of Chicago Press.

ARANTES, Rogério Bastos. (2010), Corrupção e Instituições Políticas: Uma Análise Conceitual e Empírica. Trabalho apresentado no VII Encontro da Associação Brasileira de Ciência Política. Recife, 4-7 de agosto.

BARDHAN, Pranab. (2006), The Economist's Approach to the Problem of Corruption. World Development, vol. 34, no 2, pp. 341-348.

BOURDIEU, Pierre. (2005), “O Espírito de Estado: Gênese e Estrutura do Campo Burocrático", in Razões Práticas. Campinas, Papirus, pp. 91-135.

BOZEMAN, Barry. (2007), Public Interest and Public Values. Counterbalancing Economic Individualism. Washington, Georgetown University Press.

BRASIL (2010). Constituição da República Federativa do Brasil. Brasília, Governo Federal.

BRESSER-PEREIRA, Luiz Carlos. (2001), “Gestão do Setor Público: Estratégia e Estrutura para um Novo Estado", in L. C. Bresser-Pereira e P. Spink (orgs.), Reforma do Estado e Administração Pública Gerencial. Rio de Janeiro, Editora da FGV, pp. 21-38.

CARDOSO, Fernando Henrique. (1982), Autoritarismo e Democratização. Rio de Janeiro, Paz e Terra.

CARVALHO, José Murilo de. (2008), “Passado, Presente e Futuro da Corrupção Brasileira", in L. Avritzer et alii (orgs.), Corrupção: Ensaios e Crítica. Belo Horizonte, Editora da UFMG, pp. 237-242.

DAVIS, Kenneth C. (1969), Discretionary Justice: A Preliminary Inquire. Baton Rouge, Louisiana Statute University Press.

DILLER, Matthew. (2000), “The Revolution in Welfare Administration: Rules, Discretion and Entrepreneurial Government". New York University Law Review, vol. 75, no 5, p. 1121-1220.

DOWDLE, Michael W. (2006), “Public Accountability: Conceptual, Historical, and Epistemic Mappings", in M. W. Dowdle (ed.), Public Accountability. Designs, Dilemmas, and Experiences. Cambridge, Cambridge University Press, pp. 1-32.

ETZIONI, Amitai. (2010), “Is Transparency the Best Disinfectant?". The Journal of Political Philosophy, vol. 18, no 3, pp. 389-404.

FAORO, Raymundo. (2000), Os Donos do Poder. Formação do Patronato Político Brasileiro. São Paulo, Globo.

FILGUEIRAS, Fernando. (2008), Corrupção, Democracia e Legitimidade. Belo Horizonte, Editora UFMG.

e AVRITZER, Leonardo. (2010), "Corrupção e Controles Democráticos no Brasil”, in A. dos S. Cunha; B. Medeiros e L. Aquino (orgs.), Estado, Instituições e Democracia: 


\section{Fernando Filgueiras e Ana Luiza Melo Aranha}

República. Brasília, IPEA (Coleção Perspectivas do Desenvolvimento Brasileiro, vol. I), pp. 473-504.

e BORGES FILHO, Nilson. (2005), “Estado autoritário e violência no Brasil”. Revista Portuguesa de História, tomo 37, pp. 105-130.

GALLIGAN, Dennis. (1990), Discretionary Powers: A Legal Study of Official Discretion. Oxford, Clarendon Press.

GARDINER, John. (2005), "Defining Corruption", in A. Heidenheimer e M. Johnston (eds.), Political Corruption: Concepts and Contexts. New Brunswick, Transaction Publishers, pp. 25-40.

HEALD, David. (2006), “Transparency as an Instrumental Value”, in C. Hood e D. Heald (eds.), Transparency: The Key of Better Governance. Oxford, Oxford University Press, pp. 59-73.

HUPE, Peter e HILL, Michael. (2007), "Street-level Bureaucracy and Public Accountability". Public Administration, vol. 85, no 2, pp. 279-299.

KRUEGER, Anne O. (1974), "The Political Economy of Rent-Seeking Society”. American Economic Review, vol. 64, pp. 291-303.

LEFF, Nathaniel H. (1964), "Economic Development through Bureaucratic Corruption". American Behavioral Scientist, vol. 8, no 3, pp. 8-14.

LINDSTEDT, Catharina; NAURIN, Daniel. (2010), “Transparency is Not Enough: Making Transparency Effective in Reducing Corruption". International Political Science Review, vol. 31, no 3, pp. 301-322.

LIPSKY, Michael. (2010), Street-Level Bureaucracy. Dillemas of the Individual in Public Services. New York, Russell-Sage Foundation.

LOUREIRO, Maria Rita; OLIVIERI, Cecília; MARTES, Ana Cristina Braga. (2010), “Burocratas, Partidos e Grupos de Interesse: O Debate sobre Política e Burocracia no Brasil", in M. R. Loureiro; F. L. Abrucio e R. S. Pacheco (orgs.), Burocracia e Política no Brasil. Desafios para a Ordem Democrática no Século XXI. Rio de Janeiro, Editora FGV, pp. 73-108.

; TEIXEIRA, Marco Antônio Carvalho; MORAES, Tiago Cacique. (2009), “Democratização e Reforma do Estado: O Desenvolvimento Institucional dos Tribunais de Contas no Brasil Recente". Revista de Administração Pública, vol. 43, no 4, pp. 739-772.

MARCELINO, Gileno Fernandes. (2003), “Em Busca da Flexibilidade do Estado: O Desafio das Reformas Planejadas no Brasil". Revista de Administração Pública, vol. 37, no 3, pp. 641-659.

MARE (Ministério da Administração e Reforma do Estado). (1995), Plano Diretor da Reforma do Estado. Brasília, Governo Federal.

MILLER, William. (2006), "Corruption and Corruptibility”. World Development, vol. 34, no 2, pp. 371-380.

MOTTA, Rodrigo Patto Sá. (2008), “Corrupção no Brasil Republicano - 1954-1964”, in L. Avritzer et alii (orgs.), Corrupção: Ensaios e Crítica. Belo Horizonte, Editora da UFMG, pp. 243-250. 
O'DONNELL, Guillermo. (1999), “Horizontal Accountability and New Poliarchies", in A. Schedler; L. Diamond e M. Plattner (eds.), The Self-restraining State: Power and Accountability in New Democracies. Boulder, CO, Lynne Rienner, pp. 29-51.

OFFE, Claus. (1985), Problemas Estruturais do Estado Capitalista. Rio de Janeiro, Tempo Brasileiro.

PHILP, Mark. (2005), "Conceptualizing Political Corruption”, in A. Heidenheimer; M. Johnston (eds.), Political Corruption: Concepts and Contexts. New Brunswick, Transaction Publishers, pp. 41-58.

POLLITT, Christopher. (2003), The Essential Public Manager. London, Open University Press/McGraw-Hill.

REZENDE, Flávio da Cunha. (2009), “Desafios Gerenciais para a Reconfiguração da Administração Burocrática Brasileira". Sociologias, no 21, pp. 344-365.

ROSE-ACKERMAN, Susan. (1999), Corruption and Government. Causes, Consequences and Reform. Cambridge, Cambridge University Press.

SKIDMORE, Thomas. (1999), “A Queda de Collor: Uma Perspectiva Histórica”, in K. S. Rosenn e R. Downes (orgs.), Corrupção e Reforma Política no Brasil. O Impacto do Impeachment de Collor. Rio de Janeiro, Editora da FGV, pp. 23-46.

STARLING, Heloísa Maria Murgel. (2008), “Ditadura Militar”, in L. Avritzer et alii (orgs.), Corrupção: Ensaios e Crítica. Belo Horizonte, Editora da UFMG, pp. 251-262.

TAYLOR, Matthew e BURANELLI, Vinícius C. (2007), “Ending Up in Pizza: Accountability as a Problem of Institutional Arrangement in Brazil". Latin American Politics and Society, vol. 49 , no 1 , p. 59-87.

WEBER, Max. (2002), "Burocracia”, in C. Wright-Mills e H. Gerth (eds.), Ensaios de Sociologia. Rio de Janeiro, LTC, pp. 138-170.

WERNECK VIANNA, Luiz. (1999), “Weber e a Interpretação do Brasil”. Novos Estudos Cebrap, no 53, pp. 33-47. 


\section{APÊNDICE 1 \\ METODOLOGIA DA PESQUISA COM CIDADÃOS}

A pesquisa com cidadãos refere-se a um survey nacional de opinião realizado pelo Centro de Referência do Interesse Público, em parceria com o Instituto Vox Populi, em 2008 e 2009. A pesquisa é fundamentada no método de survey, sendo aplicado a uma amostra da população brasileira um questionário estruturado. A amostra foi composta por 2.400 indivíduos, estratificada por situação de domicílio, gênero, idade, escolaridade, renda familiar e situação perante o trabalho. Este processo de estratificação é calculado proporcionalmente de acordo com os dados do Censo Demográfico do Instituto Brasileiro de Geografia e Estatística (IBGE), ano 2000, e pela Pesquisa Nacional por Amostra de Domicílios (PNAD), ano 2006. A amostra proporciona um intervalo de confiança de $95 \%$ e uma margem de erro calculada em $2 \%$. A pesquisa de campo foi realizada entre 11 e 18 de julho de 2009.

\section{APÊNDICE 2 \\ METODOLOGIA DA PESQUISA COM SERVIDORES}

A pesquisa com servidores públicos também se baseou no método de survey. Foi aplicado a uma amostra da população de servidores públicos federais, civis, do Poder Executivo, um questionário estruturado envolvendo questões relativas a cultura política, controle da corrupção e percepção sobre a atuação das instituições de controle. A amostra foi calculada em 1.115 servidores e foi estratifica proporcionalmente por ramo da administração (administração direta, autarquias e fundações), gênero, escolaridade e estado da Federação onde atua como servidor, conforme os dados do Boletim Estatístico de Pessoal do Ministério do Planejamento, Orçamento e Gestão, edição 169 de 2009. O sorteio dos indivíduos e as devidas reposições obedeceram ao cadastro do Sistema de Administração de Pessoal (SIAPE) do Governo Federal. A amostra perfaz um nível de confiança de 95,5\% e uma margem de erro $\mathrm{de}+/-3 \%$. A pesquisa de campo foi realizada entre 17 de junho e 25 de julho de 2010. 


\author{
ABSTRACT \\ Controlling Corruption in Frontline Civil Service: Rules, Discretionary \\ Power, and Reforms in Brazil
}

This article analyzes the relationship between the development of new public administration and the perception of corruption in Brazil under democratic rule. We contend that the reason for the persistently widespread perception of corruption in Brazil is that despite important changes in the institutions with oversight of the Brazilian state, such administrative reforms have assigned limited priority to frontline civil servants. Organizational progress in the new public administration has focused on upper-level public employees, with little impact on the middle and lower echelons, so that practices like graft and bribery between public employees and ordinary citizens are still commonplace. Thus, the management changes have failed to produce a perception of improvement in accountability, and corruption is still seen as common, even within a context of administrative changes.

Key words: government administration; corruption; frontline civil service; oversight; democracy

\title{
RÉSUMÉ \\ Contrôle de la Corruption et Bureaucratie en Première Ligne: Règles, Pouvoir Discrétionnaire et Réformes au Brésil
}

Dans cet article, on examine le rapport entre l'expansion de la nouvelle gestion publique et la perception de la corruption dans le Brésil démocratique. On avance que, si l'idée de la corruption persiste, malgré les changements importants dans les institutions de contrôle de l'État brésilien, c'est parce que les réformes administratives n'ont pas bénéficié aux fonctionnaires de première ligne. Malgré les progrès, en matière de gestion, de la nouvelle administration, qui favorisent les hauts fonctionnaires, les changements institutionnels n'ont pratiquement pas changé la conduite des employés de bureau en contact avec l'usager, de telle sorte que la pratique de la concussion et $\mathrm{du}$ bakchich reste fréquente dans les rapports entre fonctionnaires et citoyens. Ainsi les modifications dans la gestion ne correspondent pas, chez ces derniers, à un sentiment d'amélioration de la redevabilité du service public, ce qui préserve donc la sensation de corruption malgré ce cadre de transformations.

Mots-clés: bureaucratie publique; corruption; bureaucratie en contact avec l'usager; contrôle; démocratie 